\title{
Ranskan ja Belgian perhepalkkausjärjestelmät
}

Kirjoittanut Reino Lento.

Järjestelmän synty ja kehitys.

Vaikka palkkauksessa yleensä noudatetaankin sitä periaatetta, että työn edellyttämä korvaus maksetaan sen arvon mukaisesti, mikä työsuorituksella tuotannolle on, työnantajat ovat kautta aikojen jossakin määrin soveltaneet toistakin palkkaustapaa, jossa työsuorituksen ohella on otettu huomioon myös työntekijän tarpeet, so. hänen elatusvelvollisuutensa suuruus. Tähän ns. "perhepalkkausjärjestelmään» alettiin kiinnittää enemmän huomiota viime vuosisadan lopulla, jolloin $\mathrm{mm}$. paavi Leo XIII vuonna 1891 julkaisemassaan »Rerum novarum»-nimisessä paimenkirjeessään asettui sitä kannattamaan. Katolisen kirkon ansiota lähinnä lienee, että tämä järjestelmä vähitellen saavutti laajan levinneisyyden varsinkin Ranskassa ja Belgiassa, joiden tällä alalla saavuttamista kokemuksista on sittemmin otettu oppia monissa muissakin maissa.

Nykyaikaisen perhepalkkausjärjestelmän varsinaisena alkuunpanijana pidetään ranskalaista teollisuudenharjoittajaa Léon Harmel'ia, jọka edellä mainitun paavinkirjeen vaikutuksesta vuonna 1891 perusti Val de Bois'n tehtaisiinsa erikoisen perhekassan, jonka tarkoituksena oli jakaa ns. perhelisää (supplément familial au salaire) suurille ja sairauksien rasittamille perheille. Tämä luonnossa annettu avustus erosi kuitenkin monessa suhteessa siitä, mitä perhelisillä nykyään ymmärretään. 
Varsinaisia rahassa suoritettavia perhelisiä (allocations familiales) alettiin ensinnä maksaa erinäisissä hallintovirastoissa toimiville, esim. Ranskan tullilaitoksessa vuodesta 1899 alkaen. Vuoden 1910 paikkeilla ne tulivat käytäntöön myös pankki- ja vakuutuslaitoksissa sekä rautatieyhtiöiden piirissä, mutta laajemmassa mitassa niitä ryhdyttiin maksamaan kuitenkin vasta ensimmäisen maailmansodan aikana. Tällöin alkanut hintojen nousu saattoi varsinkin perheelliset työntekijät vaikeaan asemaan, kun palkat eivät nousseet lainkaan yhtä nopeasti kuin elinkustannukset. Senvuoksi monet työnantajat etenkin teollisuuden alalla alkoivat suorittaa erityisiä perhelisiä niille työläisilleen, joilla oli perhe huollettavanaan, koska he katsoivat, että varsinainen palkka oli riittämätön lasten tarkoituksenmukaiseen elatukseen. Myöskin virkamiehistöstä pääsivät yhä uudet ryhmät perhelisästä osallisiksi, kunnes tämä oikeus vuonna 1919 ulotettiin koskemaan virkamiehistöä kokonaisuudessaan.

Aluksi kukin työnantaja maksoi perhelisät suoraan työntekijöilleen. Tästä oli seurauksena, että perheelliset työläiset alkoivat pyrkiä niiden yritysten palvelukseen, joissa perhelisät olivat käytännössä, kun taas perheettömät niitä karttoivat. Koska nämä yritykset siten joutuivat huonompaan asemaan kuin niiden kilpailijat, alettiin ennen pitkää pitää toivottavana, että kaikki saman alan tai saman alueen työnantajat saataisiin maksamaan alaisilleen perhelisää samojen perusteiden mukaan. Oli koetettava saada heidät liittymään jäseniksi tasauskassaan, jolle kukin heistä maksaisi määräsumman kutakin työläistään kohden tai määräprosentin palkkatilinsä yhteissummasta ja joka sitten näin kertyvistä varoista suorittaisi työläisille perhelisät. Työnantajille tulisi silloin olemaan yhdentekevää, oliko heidän työläisillään lapsia vaiko ei.

Ensimmäinen tällainen tasauskassa (caisse de compensation) saatiin aikaan Grenoblen seudun metalliteollisuudessa vuonna 1918. Ajatuksen omaksuivat ennen pitkää mainitun seudun muutkin teollisuudenhaarat, ja sitten järjestelmä asteittain levisi yhä laajemmalle, niin että perhelisistä nopeasti pääsivät osallisiksi huomattavat osat teollisuuden ja kaupan alalla toimi- 
vista. Jo vuonna 1920 kassojen luku oli 56 ja viisi vuotta myöhemmin 183. Vuonna 1930, jolloin kassojen luku oli noussut 230:een, perhelisistä pääsi osallisiksi noin 1.880 .000 työläistä. $^{1}$

Belgiassa kehitys kulki samaan suuntaan kuin Ranskassakin. Ensimmäinen tasauskassa perustettiin siellä vuonna 1921, mutta jo vuotta aikaisemmin Belgian valtio oli seurannut Ranskan esimerkkiä ja ruvennut maksamaan perhelisää kaikille virkamiehilleen.?

Kuten edellä jo mainittiin, oli niiden työnantajien tarkoituksena, jotka ensimmäisinä ryhtyivät perhelisiä maksamaan, lähinnä helpottaa sellaisten työläisten asemaa, joiden talous inflaation johdosta joutui kovimmin koetelluksi. Uudistusta perusteltiin kuitenkin myös sillä, että se tulisi johtamaan työläisten tulon oikeudenmukaisempaan jakoon, kun suoritukseen perustuva palkka tulisi korvatuksi palkalla, jossa ainakin osaksi oli otettu huomioon myös työläisen ja hänen perheensä tarpeet. Järjestelmän toivottiin myös takaavan lapsille tehokkaamman hoidon, lisäävän syntyvyyttä sekä liittävän työnantajat ja työntekijät lähemmin tơisiinsa.

Näihin sosiaalișiin näkökohtiin liittyi myös taloudellinen tekijä, jonka merkitys oli ainakin yhtä suuri. Aikana, jolloin elinkustannukset nopeasti kohosivat, työnantajat huomasivat perhelisäjärjestelmän käyttökelpoiseksi menetelmäksi järjestellä palkat itselleen vähimmin rasittaviksi. Perhelisien avulla kävi mahdolliseksi välttää yleinen palkankorotus antamalla elinkustannusten nousua enemmän tai vähemmän tarkoin vastaava palkanlisä vain niille työläisille, joilla oli perhe huollettavanaan. Rahan arvon laskiessa tuli siten se lapsiavustus, joka nimellisesti näytti palkanlisältä, olemaan vain osittainen korvaus siitä erotuksesta, mikä oli syntynyt palkan aikaisemman ja silloisen ostokyvyn välille. Eräät työnantajat pitivätkin perhelisiä ennen kaikkea keinona palkkamenojensa kokonaismäärän supistamiseksi. Toiset heistä taas toivoivat saavansa niiden avulla perheelliset työläiset asettumaan vastahankaan ammattiyhdistysliikkeeseen nähden ja ehkäistyksi työvoiman liiallisen vaihtumisen. ${ }^{3}$ 
Ammattiyhdistysten taholta perhelisäjärjestelmä aluksi kohtasi ankaraa vastarintaa. Vaikka ne kannattivatkin tarpeen mukaista palkkaa, ne eivät kuitenkaan hyväksyneet työnantajien aloitetta tällä alalla, vaan väittivät heidän siten vain pyrkivän heikentämään työväenluokan ja ammattiyhdistysten yhteistuntoa ja lamauttamaan palkkojen korottamista tarkoittavia ponnistuksia. Ne kielsivät työnantajien oikeuden sekaantua valheellisen hyväntekeväisyyden varjolla työläisperheiden suojeluun sekä syntyvyyden lisäämiseen ja katsoivat tällaisten asioiden kuuluvan yhteiskunnalle kokonaisuudessaan.

Mutta ammattiyhdistysten vastarinta ei kyennyt estämään perhepalkkausjärjestelmän leviämistä. Sotaa seuranneina vuosina palkkojen nousu jäi siinä määrin jälkeen elinkustannusten noususta, että useimmat työläiset tervehtivät tyydytyksellä jokaista toimenpidettä, joka oli omiaan helpottamaan heidän taloudellista ahdînkoaan. Järjestelmän yleistyessä ammattiyhdistyksetkin ottivat siihen nähden suvaitsevaisemman asenteen. Ne alkoivat nyt vaatia perhepalkkausjärjestelmän tekemistä yleiseksi ja pakolliseksi, sillä edellytyksellä, että valtio rahoittaisi tai tukisi sitä ja ottaisi huostaansa sen ylimmän valvonnan ja että kassojen hallintoon työnantajien ohella osallistuisivat myös työntekijät ja valtio. Jo vuonna 1920 eräs kansanedustaja teki Ranskassa tätä tarkoittavan lakialoitteen.

Työnantajat asettuivat kuitenkin näihin suunnitelmiin nähden jyrkästi kielteiselle kannalle. Tämä johtui osaksi siitä, että mainitun aloitteen mukainen laki olisi nostanut miltei kolminkertaisiksi ne kustannukset, joita perhelisistä heille siihen aikaan oli, osaksi siitä, e ${ }^{t}$ tä he eivät olisi enää saaneet yksin hoitaa tasauskassoja, vaikka olisivat edelleenkin joutuneet yksin kantamaan kaikki järjestelmästä aiheutuvat kustannukset. Taloudellisen vapauden periaatteellisina kannattajina he eivät myöskään voineet hyväksyä ehdotettua valtion valvontaa.

Työnantajien rintama ei ollut kuitenkaan tässä asiassa täysin yhtenäinen. Kassojen jäseniksi liittyneet rakennus- ym. urakoitsijat olivat joutuneet toteamaan, miten sellaiset yritykset, jotka eivät maksaneet työläisilleen perhelisää, saattoi- 
vat tehdä alhaisempia hankintatarjouksia ja siten syrjäyttää heidät esim. valtion hankinnoista kilpailtaessa. He kannattivat senvuoksi perhelisien tekemistä yleisiksi ja pakollisiksi. Vaikka mainittu lakialoite ei johtanutkaan toivottuun tulokseen, asia tuli urakoitsijoiden osalta kuitenkin autetuksi: vuoden 1922 lopulla julkaistu laki sääsi, että kaikkiin yleisiä töitä koskeviin sopimuksiin oli sisällytettävä määräys, joka velvoitti urakoitsijan suorittamaan työläisilleen perhelisää. Belgiassa vastaavanlainen laki hyväksyttiin vuonna $1928 .^{4}$

Ennen pitkää muutkin työnantajat joutuivat tarkistamaan kantaansa asiaan nähden. Yleismaailmallisen pulakauden ulottaessa 1920-luvun lopulla vaikutuksensa Ranskaan ja Belgiaankin perhepalkkausjärjestelmän kehitys pysähtyi, ja näytti uhkaavan vaara, että yhä useammat yritykset katsoisivat parhaaksi siitä lıopua. Keskinäisen kilpailun kiristyessä alkoivat tasauskassoihin liittyneet työnantajat yhä enemmän kallistua sille kannalle, että se taloudellinen rasitus, jonka he vapaaehtoisesti olivat ottaneet kannettavakseen, oli ulotettava koskemaan myös heidän kilpailijoitaan. Näin oli maaperä valmis valtion asiaanpuuttumiselle.

Ensimmäisenä ehti tämän ratkaisevan askeleen ottaa Belgia. Elokuun 4 päivänä 1930 annetulla làilla siellä vakiinnutettiin ne tulokset, jotka vapaaehtoista tietä syntyneellä perhepalkkausjärjestelmällä oli siihen mennessä saavutettu. Samalla se perhelisien maksuvelvollisuus, joka v. 1928 oli asetettu valtion urakoitsijoille, ulotettiin koskemaan jokaista työnantajaa, toimivatpa nämä sitten teollisuuden, kaupan, maatalouden tai muilla aloilla, samoin myös valtiota ja kuntia niin hyvin varsinaisten* työläisten kuin virkamiestenkin osalta. Jokainen työnantaja, jolla oli palveluksessaan yksi tai useampia henkilöitä, velvoitettiin liittymään johonkin tasauskassaan, jonka hän yleensä sai itse valita. Valtio, kunnat sekä erinäiset yleishyödylliset laitokset saivat kuitenkin oikeuden suorittaa perhelisät virka- ja palveluskunnalleen suoraan. Kassoihinliittymis- ja kannatusmaksujen suoritusvelvollisuudesta vapautettiin myös eräät vähäisemmät työnantajaryhmät, joiden palveluksessa olevien perhe- 
lisät rahoitettiin muuta tietä, lähinnä valtion varoilla. Näihin kuuluivat $\mathrm{mm}$. ne työnantajat, joilla oli palveluksessaan yksinomaan heidän luonaan asuvia henkilöitä, kalastajat, joilla ei ollut omaa venettä, sekä erinäiset kotonaan työskentelevät käsityöläiset. Nämä poikkeussäädökset aiheuttivat sittemmin käytännössä vaikeuksia, kun työnantajat pyrkivät tulkitsemaan niitä mielivaltaisesti.

Perhelisää oli lain mukaan suoritettava kaikille työsuhteessa oleville samoin kuin myös niille, jotka saivat vanhuus- tai työkyvyttömyyseläkettä. Ehtona kuitenkin oli, että ko. työ oli säännöllistä ja riittävää. Mainitut henkilöt olivat oikeutetut saamaan perhelisää kustakin huollettavanaan olevasta 14 vuotta nuoremmasta lapsestaan, tai 18 vuotta nuoremmasta siinä tapauksessa, että lapsi jatkoi opintojaan tai oli ammattiopissa. Mitään ikärajoitusta ei ollut niihin lapsiin nähden, jotka henkisen tai ruumiillisen vajavaisuutensa vuoksi olivat ammattiin kykenemättömiä. Merkille pantavaa on, että perhelisää maksettiin myös työläisen huollettavina olevista nuoremmista veljistä ja sisarista.

Belgian laki pyrki yhdenmukaistamaan eri paikkakunnilla ja eri toimialoilla vallinnutta käytäntöä siten, että se saattoi voimaan koko maata koskevan perhelisien minimiasteikon, jonka mukaan ensimmäisestä lapsesta oli suoritettava vähintään 15 frangia, toisesta 20 , kolmannesta 40 , neljännestä 70 ja kustakin seuraavasta lapsesta 100 frangia kuukaudessa. Myöskin työnantajien suoritettaville kannatusmaksuille vahvistettiin yhdenmukaiset perusteet. Lisäksi luotiin eräänlainen toisen asteen tasausjärjestelmä perustamalla erikoinen kansalliskassa ensiasteisten kassojen yhdyssiteeksi. Mikäli kansalliskassa ei kyennyt peittämään niitä vajauksia, joita yksityisten kassojen tileissä syntyi niiden toimipiirin suuresta lapsiluvusta johtuen, hallitus maksoi erotuksen sen käytettäväksi asetetusta 30 miljoonan frangin avustusmäärärahasta, joka kuitenkin lähinnä oli tarkoitettu kolmannesta ja sitä seuraavista lapsista suoritettavien perhelisien maksamista varten. ${ }^{5}$ 
Ranskassa perhepalkkausjärjestelmä tehtiin pakolliseksi maaliskuun 11 päivänä 1932 annetulla lailla. Belgian lain tavoin sekin velvoitti jokaisen työnantajan, joka säännöllisesti piti palveluksessaan palkattua työvoimaa, liittymään jäseneksi johonkin tasauskassaan. Laki koski kaikkia työsuhteessa olevia, lukuun ottamatta virkamiehiä, joilla oli oma, vuoden 1919 lakiin perustuva perhelisäjärjestelmänsä, sekä kotiapulaisia. Perhelisää oli maksettava myös työssä sattuneen tapaturman johdosta työkyvyttömäksi tulleen taikka kuolleen lapsille. Ikärajana tuli olemaan 13 vuotta, paitsi milloin lapsi jatkoi opintojaan, oli ammattiopissa taikka työhön kykenemätön, jolloin se oli 16 vuotta.

Ranskan laki erosi siinä suhteessa vastaavasta Belgian laista, että se koetti säilyttää siihenastisen järjestelmän mahdollisimman suuressa määrässä muuttamattomana. Ranskaan ei vielä tässä vaiheessa luơtu koko maata käsittäviä toisen asteen tasauskassoja eikä liioin mitään yhtenäistä perhelisien minimiasteikkoa. Kassoihin liittyminen oli oikeastaan ainoa velvollisuus, jonka laki työnantajille asetti. Kaikki järjestelmän yksityiskohdat kuten perhelisien suuruus, kannatusmaksujen määrä ja laskutustapa ym. jätettiin kunkin kassan itsensä ratkaistaviksi. Perhelisiin nähden oli kuitenkin kullekin departementílle erikseen vahvistettu omat minimimääränsä, joita ei ollut lupa alittaa.

Laki saatettiin voimaan asteittain vuosien kuluessa, koska vallitsevan lamakauden takia koetettiin pidättyä asettamasta yrityksille uusia odottamattomia rasituksia. Teollisuuden, kaupan ja vapaiden ammattien aloilla lain soveltaminen ei tuottanut sanottavampia vaikeuksia, mutta maataloudessa sen toimeenpano oli hankalampaa. Täällä kohdattiin melkoista vastustusta, mitä kyllä oli osattu odottaakin. Vaikeuksia tuottivat $\mathrm{mm}$. viljelmien erilaiset olosuhteet, päähenkilöä avustavien perheenjäsenten asema ja ennen kaikkea se seikka, että väestön mieliä ei oltu tarpeeksi valmistettu ymmärtämään uudistuksen tarkoitusta. Järjestelmä tehtiin maataloudessa pakolliseksi vasta vuonna 1936 , mutta silloinkin se tuli koskemaan vain niitä 
työnantajia, joilla oli palvelusväkeä vähintään 75 päivänä vuodessa. Kaksi vuotta myöhemmin otettiin mukaan vähäisemmätkin työnantajat, niin että perhelisistä nyt pääsi osalliseksi käytännöllisesti katsoen koko maalaisväestö. ${ }^{6}$

On selvää, että näin alulle saadussa lainsäädännössä huomattiin ennen pitkää olevan paljonkin muuttamisen ja täydentämisen varaa. Jo vuoden 1930 lakia säädettäessä eräät Belgian edustajakamarin jäsenet vaativat, että perhelisistä oli päästävä osallisiksi muidenkin kuin palkannauttijoiden. He osoittivat, että hyvin monet pikku työnantajat, kauppiaat, käsityöläiset ja maanviljelijät itse asiassa olivat huonommassa asemassa kuin eräät palkannauttijaryhmät. Olisi väärin, jos ensiksimainitut velvoitettaisiin maksamaan palveluksessaan oleville perhelisää, vaikka heillä itsellään saattoi olla huollettavanaan monilapsinen perhe, jonka ylläpitoa varten he eivät saaneet mitään avustusta.

Muutosehdotus ei sillä kerralla saanut puolelleen tarvittavaa kannatusta, mutta Belgian »Suurten perheiden liiton» harjoittaman propagandan ansiosta yleinen mielipide vähitellen alkoi kallistua ajatukselle suopeaksi. Tuloksena oli kesäkuun 10 päivänä 1937 julkaistu laki, joka ulotti perhelisäjärjestelmän koskemaan muitakin kuin palkannauttijoita. Perhelisistä pääsivät nyt osallisiksi mm. käsityöläiset ja muut riippumattomat työntekijät, teollisuuden työnantajat, kauppiaat ja maanviljelijät sekä vapaiden ammattien harjoittajat. Täten Belgia, joka ennen Ranskaa oli ehtinyt toteuttaa pakollisen perhelisäjärjestelmän palkannauttijoiden osalta, ehti myös ennen sitä laajentaa järjestelmän kaikkia yhteiskuntaluokkia koskevaksi.

Belgian järjestelmään myöhemmin tehdyt muutokset koskevat ennen kaikkea sen organisaatiota. Joulukuun lopussa 1944 saatettiin palkannauttijoiden perhelisiin tarvittavien varojen kanto Belgian yleisen sosiaalivakuutusjärjestelmän puitteisiin. Perhelisät jäivät tältä osalta edelleenkin kokonaan työnantajien rasitukseksi, joiden oli tarkoitusta varten suoritettava $6 \%$ maksamistaan palkoista, mutta suoritus tuli vastedes tapahtumaan yleisen sosiaalivakuutusmaksun yhteydessä. Kertyneistä mak- 
suista luovutetaan perhelisille kuuluva osuus näiden kansalliselle tasauskassalle, joka sitten jakaa ne sen jäseninä oleville primäärisille kassoille. Itsenäisillä työläisillä on omat virallisesta järjestelmästä riippumattomat keskinäiset kassansa, jotka keräävät perhelisiin tarvittavat varat jäseniltään näiden tulojen suuruuden ym. seikkojen perusteella. Työnantajilla on niinikään omat kassansa. Vuoden 1947 alussa hallitus asetti erikoisen toimiston suunnittelemaan näiden erilaisten kassojen liittämistä yhdeksi ainoaksi kokonaisuudeksi.

Muista Belgian järjestelmään viime vuosina tehdyistä muutoksista mainittakoon vielä, että palkkatyöläisille suoritettavien perhelisien alin luvallinen määrä nostettiin vuoden 1947 lopulla siten, että se tuli olemaan perheen ensimmäisestä ja toisesta lapsesta 200 frangia kummastakin, kolmannesta 270 , neljännestä 350 ja viidennestä sekä seuraavista $500 \mathrm{fr}$. kuukaudessa. Puoleksi orvon osalta perhelisä on $700 \mathrm{fr}$. ja täysin orvon $940 \mathrm{fr}$. kuukaudessa. Itsenäisille työntekijöille suoritettavat erät nousevat samaan tapaan lapsen järjestysluvusta riippuen, mutta ne ovat määrältään paljon pienempiä.

Ranskassa perhelisäjärjestelmän kehitykseen vaikutti ennen kaikkea se, että maan hallitus - huolissaan syntyvyyden jatkuvasta alenemisesta - alkoi käyttää sitä yhä kasvavassa määrässä väestöpolitiikkansa välikappaleena. Tämä käy selvästi ilmi niistä muutoksista, joita lainsäädäntöön tehtiin vuonna 1938 . Niinpä yhdestä ainoasta lapsesta suoritettu perhelisä määrättiin nyt lakkaamaan lapsen täytettyä 5 vuotta. Perhelisiä korotettiin ja lisäksi otettiin käytäntöön erikoinen »kotona olevan äidin lisä» (allocation de la mère au foyer), jonka pääasiallisimpana tarkoituksena oli houkutella äitejä jättämään ansiotyö ja jäämään kotiin. Se lisättiin varsinaiseen perhelisään, jos äiti — tai isoäiti, mikäli hän huolehti lapsesta - ei ollut ansiotyössä. Muista lainmuutoksista mainittakoon toisen asteen tasausjärjestelmän luominen primääristen kassojen yläpuolelle sekä perhelisien maksutavan muuttaminen siten, että ne tästä Iähtien tulivat olemaan määräprosentti departementin keskimääräisestä palkasta. 
Kaikki Ranskan perheiden avustamista tarkoittavat toimenpiteet tarkistettiin ja liitettiin yhdeksi kokonaisuudeksi heinäkuun 29 päivänä 1939 annetulla lailla, joka tunnetaan nimellä Code de la Famille. Sen tarkoituksena oli toteuttaa sellainen yhteiskunnallinen uudistus, joka olisi omiaan lisäämään syntyvyyttä ja parantamaan Ranskan perheiden hyvinvointia siinä määrin, että suurten perheiden luku voisi lisääntyä. Monien muiden toimenpiteiden ohella laki sisälsi myös perhelisää koskevat säädökset, joihin nyt tehtiin huomattavia muutoksia. Tärkein niistä oli se, että järjestelmän piiriin tulivat tästä lähtien kuulumaan kaikkien ammattialojen palkannauttijoiden ohella myöskin tyồnantajat sekä itsenäiset työntekijät, lyhyesti sanottuna kaikki ammatissatoimivat. Ilman lapsilisiä jäivät edelleenkin ne perheet, jotka saivat yksinomaan työtöntä tuloa kuten koroillaan elävät sekä eläkkeellä olevat. Maksujen suoritus jäi entiseen tapaan tasauskassojen huoleksi.

Muista uudistuksista mainittakoon, että käytännössä olleet perhelisäjärjestelmät liitettiin nyt yhtenäiseksi systeemiksi, niin että perhelisä tuli olemaan - jos paikkakunnalliset eroavaisuudet jätetään huomioon ottamatta - kaikille siihen oikeutetuille yhtä suuri. Ensimmäisestä lapsesta suoritettu perhelisä poistettiin nyt kokonaan ja korvattiin kertakaikkisella synnytyspalkkiolla, kun taas kolmannesta ja sitä seuraavista lapsista maksettavaa perhelisää korotettiin. Järjestelmän rahoituksessa tuli valtion avustuksella tästä lähtien olemaan huomattava osuutensa. Tämän sekä muiden väestöpoliittisten menojen peittämiseksi verotus samalla uudistettiin siten, että se entistä enemmän otti huomioon kunkin huoltovelvollisuuden ja siitä aiheutuvan veronmaksukyvyn alenemisen.

Vielä vuoden 1939 jälkeenkin Ranskan perhelisăjärjestelmä on ollut monien muutosten alaisena. Niinpä siellä v. 1941 otettiin käytäntöön erikoinen »yhden palkan lisä» (allocation de salaire unique). Maan vapauduttua saksalaisten miehityksestä siellä seurattiin Belgian esimerkkiä ja säädettiin lokakuun 4 päivänä 1945 annetulla lailla perhelisien hallinto- ja rahoitusjärjestelmä liitettäväksi yleiseen sosiaalivakuutusjärjestelmään. 
Viimeksimainittua järjestelmää kehitettiin edelleen elokuun 28 päivänä 1946 annetulla lailla, joka samalla peruutti osan perhelisistä aikaisemmin annettuja säädöksiä. ${ }^{7} \quad$ Näiden tiheiden lainmuutosten takia on syytä esitellä Ranskan nykyistä perhelisäjärjestelmää vähän seikkaperäisemmin, etenkin kun se muutenkin on monivivahteisempi kuin Belgian järjestelmä.

Ranskan nykyisen perhelisäjärjestelmän pääpiirteet.

P erhelisään oikeutetut. Kuten edellä esitetystä on käynyt selville, Ranskassa on ollut käytännössä kolme eri perhelisämuotoa, nim. varsinainen perhelisä, kotona olevan äidin lisä ja yhden palkan lisä.*

Varsinaista perhelisää maksetaan nykyään toisesta lapsesta alkaen periaatteessa kaikille perheenhuoltajille paitsi niille, jotka eivät ole hyödyllisessä työssä, vaikka he sellaiseen pystyisivät. Palkannauttijoiden ohella siitä pääsevät siis osallisiksi myös itsenäiset työntekijät, työnantajat ym. ammatissatoimivat.

Yhden palkan lisää suorítetaan jo ensimmäisestä lapsesta lähtien, mutta vain palkannauttijoille - myös julkisissa toimissa oleville - mikäli perhe saa toimeentulonsa yhdestä ainoasta tulonlähteestä. Tämän tulon ansaitsijana voi olla perheen isä, äti tai joku ylenevän polven sukulainen, joka on ottanut huolehtiakseen lapsista. Käytännössä tätä ehtoa on tulkittu siten, että perhe ei menetä ko. oikeuttaan, vaikka isän ohella äitikin olisi ansiotyössä, kunhan hän ei ole poissa kotoa enempää kuin puolen päivää ja kun hänen ansionsa jää määrättyä summaa pienemmäksi. Myöskään lasten mahdollisesti saamat tulot eivät vaikuta asiaan.

Kotona olevan äidin lisää on Code de la Famille'n mukaan maksettava asutuskeskuksissa, joiden väkiluku ylittää 2.000 henkeä, sellaisille palkannauttijaperheille, joiden toimeentulo on

- Aitiys- ja raskausavustukset on tässä jätetty huomioon ottamatta. 
riippuvainen yhdestä tulonlähteestä. Kun yhden palkan lisä otettiin käytäntöön vuonna 1941 , säädettiin, ettei sitä saanut maksaa sellaisille perheille, jotka jo ennestään saivat kotona olevan äidin lisää. Koska viimeksimainittu niistä on suppeampi, se pian menetti käytännöllisen merkityksensä.

Perhelisää maksetaan - paitsi ammatissatoimiville - myöskin kaikille jotka ovat hyödylliseen työhön kykenemättömiä. Näihin kuuluvat $\mathrm{mm}$. naiset, joilla on huollettavanaan kaksi tai useampia lapsia, perhelisää saaneiden lesket, vanhuuseläkkeen tai -avustuksen saajat, täysin työkyvyttömät invaliidit, työssä sattineen tapaturman johdosta työkyvyttömiksi tulleet, sairaustai äitiysavustuksen saajat sekä rekisteröidyt työttömät. Lisäksi perhelisä voidaan suorittaa muillekin henkilöille, jotka osoittavat olevansa ansiotyöhön kykenemättömiä ikänsä, terveydentilansa, ammattiopintojen harjoittamisen ym. seikkojen takia.

Perhelisän saamisen yleisenä edellytyksenä on, että perheessä on huollettavia lapsia, olivatpa nämä sitten omia tai ottolapsia. Siihen oikeutettuja ovat myöskin ne henkilöt, jotka vastaavat joko lastenlastensa taikka alaikäisten veljiensä tai sisartensa taikka veljen- tai sisarenlastensa toimeentulosta, niinikään ne, jotka pysyvästi huolehtivat täysin vieraiden lapsista.

Lapsesta maksetaan perhelisää niin kauan kuin hän on oppivelvollisuusiässä ja - ellei hän mene ansiotyöhön - vielä vuosi sen jälkeenkin eli 15 vuoden ikään asti. Ikäraja nousee kuitenkin 17 vuoteen niiden lasten osalta, jotka ovat ammattiopissa, ja 20 vuoteen niiden osalta, jotka jatkavat opintojaan tai jotka heikkouden taikka parantumattoman sairauden vuoksi ovat ansiotyöhön kykenemättömiä. Viimeksi mainittuun ikään asti voidaan perhelisää maksaa myös tytöstä, joka on kokonaan omistautunut kotinsa kotitaloustoimille tai vähintään kahden 10 vuotta nuoremman lapsen hoitoon.

Perhelisän suuruus. Sekä varsinainen että yhden palkan lisä määritellään nykyään prosenttina paikkakunnan keskimääräisestä kuukausipalkasta, joka määräajoin lasketaan erikseen kaupunkien ja maaseudun sekä kunkin departementin 
osalta, käyttäen pohjana sitä tuntipalkkaa, joka kulloinkin on vahvistettu metalliteollisuuden ammattitaidottomille työläisille Seinen departementissa.

Varsinaisen perhelisän suuruus on nykyään $20 \%$ mainitulla tavalla lasketusta departementin palkasta perheen toisen lapsen osalta ja $30 \%$ kolmannesta sekä kustakin sitä seuraavasta lapsesta. Yhden palkan lisä on - jos lapsia on vain yksi - 20\% ko. palkasta, niin kauan kuin lapsi on viittä vuotta nuorempi, ja sen jälkeen $10 \%$. Kahdesta lapsesta maksetaan tätä perhelisää $40 \%$ ja kolmannesta tai useammasta lapsesta $50 \%$ mainitusta palkasta.

Se tulojen kasvu, mitä perhelisä siihen oikeutetulle merkitsee, voi siis muodostua hyvin huomattavaksi, jos asianomaisella on useampia lapsia ja jos hänen palkkansa on alhainen departementin laskettuun palkkaan verrattuna. Niinpä sellainen palkannauttijaperhe, jolla on huollettavanaan kolme lasta, joka saa toimeentulonsa vain yhdestä työstä ja jonka tulo vastaa departementin laskettua keskimääräistä palkkaa, saa perhelisän ansiosta tulonsa kaksinkertaistetuksi.

Yllä mainitut perhelisien määrät ovat kuitenkin vain minımimääriä, joita tasauskassoilla on oikeus ylittää. Etenkin viime sodan aikana kassat yleisesti maksoivat perhelisät korotettuina ja ottivat käytäntöön erilaisia muita avustuksia kuten kalliinajan- ja vuokranlisät, synnytyslisät ym. Sitäpaitsi ne kehittivät edelleen niitä monia sosiaalisen hyväntekeväisyyden muotoja, joita ne jo vanhastaan olivat harjoittaneet. Niinpä ne ovat panneet toimeen vaatteiden jakeluja, hankkineet äideille kotitalousapua, järjestäneet lapsille tilaisuuksia viettää loma-aikansa maaseudulla, avustaneet vanhuksia ja tapaturman uhriksi joutuneita sekä järjestäneet elämänuranvalinnan ohjausta nuorille, kotitalouskursseja, lääkärinapua, virkistystilaisuuksia ym.

M a ks u a pa. Vaikka lain mukaan perheenisällä onkin ensisijainen oikeus perhelisän nostamiseen, on perhelisä käytännössä kuitenkin maksettu suoraan äidille siinäkin tapauksessa, että se on myönnetty isän työpaikan perusteella. Maksu ta- 
pahtuu kuukausittain tai neljännesvuosittain, mutta yhden vuoden perhelisää vastaava pääoma-arvo voidaan suorittaa yhdellä kertaa ennakolta, jos sen katsotaan olevan lapsen etujen mukaista. Nykyään maksut tapahtuvat enimmäkseen tasauskassojen kautta ja postitse. Monet Pariisin kassat toimittavat kuitenkin perhelisät asiamiestensä välityksellä suoraan työläisten koteihin.

Sen seikan varmentamiseksi, että perhelisät todella tulevat käytetyiksi oikeaan tarkoitukseensa, on säädetty, että jos tutkimus osoittaa lasta kasvatettavan olosuhteissa, jotka ravinnon, asunnon tai muuten terveydellisten seikkojen puolesta ovat epätyydyttävät, perhelisä voidaan maksaa prefektin määräämälle kaitsijalle, jonka velvollisuutena on huolehtia siitä, että rahat tulevat käytetyiksi yksinomaan lasten ja kodin hyväksi.

$\mathrm{R}$ a hoitus. Ne kustannukset, jotka aiheutuvat teollisuuden, kaupan ja vapaiden ammattialojen palkannauttijoille maksettavista perhelisistä, ovat kokonaan ao. työnantajien rasituksena. Sensijaan valtio osallistuu niihin kustannuksiin, joita perhelisistä koituu maataloudenharjoittajille, käsityöläisille ja muille itsenäisille työntekijöille.

Se summa, jonka työnantajat tarkoitusta varten suorittavat, oli ensi aluksi verraten vaatimaton, nousten esim. vuonna 1938 keskimäärin noin 3,5\%:iin heidän palkkatiliensä loppusummasta. Kun perhelisiä seuraavana vuonna korotettiin, arvioitiin keskimääräisten kustannusten sen johdosta nousseen noin 5-6\%:iin. Sodan aikana tapahtuneet lisäkorotukset nostivat tämän kustannuserän keskimäärin noin $9 \%$ :iin palkoista, yksityisten työnantajien osuuden vaihdellessa heidän toimialastaan ja paikkakunnasta riippuen 4 stä 16:een $\%$ :iin. Kun perhelisiin tarkoitetut erät sodan päätyttyä alettiin kantaa yleisen sosiaalivakuutusmaksun yhteydessä, tämä rasitus tuli eri työnantajaryhmille yhdenmukaisemmaksi. Maksettavaa määrää on kuitenkin inflaation edistymisen takia ollut pakko jatkuvasti korottaa, kun palkat ovat jääneet jälkeen elinkustannuksista samaan tapaan kuin edellisenkin maailmansodan päätyttyä. Ol- 
tuaan aluksi $12 \%$ työläisten palkoista se lokakuun alusta 1947 nostettiin 13:een ja maaliskuun alusta 1948 14\%:iin. Todennäköisesti sitä joudutaan vast'edeskin vielä korottamaan ehkäpä monestikin.

Itsenäisten työntekijöiden samoin kuin työnantajien omiin perhelisiinkin tarvittavat varat kerätään näiden omasta piiristä. Ensiksi mainittuja valtio avustaa suorittamalla tavallisimmin $40 \%$ heidän perhelisistään, mutta eräille ryhmille avustus on vain $20 \%$ toisten jäädessä aivan ilman. Lokakuun alusta 1947 itsenäisten työntekijöiden suorituksen suuruus vaihtelee 4-10 \%:iin siitä palkasta, joka departementin pääkaupungissa maksetaan raskaasta, ei ammattitaitoa vaativasta työstä. Toiset heistä voidaan kuitenkin vapauttaa suorituksesta esim. korkean ikänsä, pienen palkkansa tai sen seikan perusteella, että he ovat kasvattaneet täyteen ikään vähintään neljä lasta. Työnantajat puolestaan maksavat summan, joka vastaa $10 \%$ samasta ammattitaidottoman työläisen palkasta. Maa- ja metsätaloudessa toimivien henkilöiden perhelisät rahoitetaan jossakin määrin erilaisin perustein. Osa tarvittavista varoista saadaan maanviljelijöiden suorituksista, jotka on laskettu heidän maansa verotusarvon mukaisesti, osa maataloustuoteverojen avulla.

H a 11 in to. Perhelisäasioiden hoito on Ranskassa parhaillaan eräänlaisessa ylimenovaiheessa. Tarvittavien varojen kanto tapahtuu muiden sosiaalivakutuusmaksujen yhteydessä niiden sosiaalivakuutuskassojen toimesta, jotka ovat sodan jälkeen sosiaalista turvallisuutta varten luodun hallintojärjestelmän paikallisia yksiköitä. Tarkoituksena on, että nämä primääriset kassat yhdessä piirikassojen sekä kansallisen sosiaalivakuutuskassan kanssa tulevaisuudessa huolehtisivat perhelisäasioiden hoidosta ja jakaisivat perhelisät samaan tapaan, kuin nyt jo on laita sosiaalivakutuuksen edellyttämiin maksuihin nähden. Toistaiseksi perhelisien jakelu kuitenkin tapahtuu entisten tasauskassojen välityksellä, jotka saavat edellämainitulla tavalla kertyneistä varoista niille kuuluvan osan. 
Eräitä perhelisäjärjestelmään liittyviä kysymyksiä ja näkökohtia.

Perhelisän käsite. Ranskan ja Belgian perhepalkkalainsäädännössä määriteltiin perhelisä (allocation familiale) alun perin rahasummaksi, jonka työnantaja säännöllisin väliajoin suorittaa perheenhuoltajalle tämän varsinaisen palkan lisâkksi ja jonka suuruus ei ole riippuvainen työläisen taitavuudesta ja työtehosta, vaan hänen huoltovelvollisuudestaan, so. hänen määrättyä ikärajaa nuorempien lastensa luvusta.

Tämä määritelmä on sittemmin järjestelmän kehittyessả vanhentunut. Belgiassa alettiin perhelisiä maksaa muillekin kuin palkannauttijoille vuoden 1937 lain perusteella ja Ranskassa kaksi vuotta myöhemmin. Täten perhelisät menettivät kiinteän kosketuksensa palkkoihin. Perhelisistä tulivat osallisiksi kaikki ne perheet, jotka kasvattivat lapsia, koska tämä tehtävä katsottiin mitä suuriarvoisimmaksi yhteiskunnalliseksi palvelukseksi. Perhelisä ei tullut kuitenkaan olemaan mikään huoltoon rinnastettava avustus, vaan sitä suoritettiin kaikille perheenhuoltajille taloudellisesta asemasta riippumatta. Siitä tuli siis eräänlainen kansalaisoikeus, joka perustui periaatteelle, 'että kansantulo olisi jaettava kunkin huoltovelvollisuuden mukaisesti.

Kun perhelisää täten alettiin pitää kansallisen solidariteetin ilmauksena, järjestelmä alkoi yhä enemmän muistuttaa sosiaalivakuutusta. Niinpä Belgiassa muut kuin palkannauttijat maksavat itse perhelisistä aiheutuvat kustannukset, samoin myös Ranskassa työnantajat ja riippumattomat työläiset, jotapaitsi valtio osallistuu huomattavassa mitassa kustannuksiin verotuloillaan, kuten edellä on esitetty. Kummassakin maassa on perhelisiin tarvittavien varojen kanto jo uskottu sosiaalivakuutuskassoille, ja on vain ajan kysymys, milloin näiden varojen jakelukin siirtyy mainittujen kassojen haltuun. Vanhat tasauskassat ovat silloin näytelleet osansa loppuun, ja perhepalkkajärjestelmä on osoittautunut vain erääksi välivaiheeksi yleisiin lapsieläkkeisiin johtavassa kehityksessä. 
Perhelisät ja tuotantokustannukset. Kuten edellä on osoitettu, perhelisät ovat etenkin Ranskassa alkaneet muodostaa työnantajien palkkamenoista yhä kasvavan prosenttimäärän, toisin sanoen heidän tuotantokustannuksensa ovat niiden johdosta jatkuvasti kasvaneet. Tämä on sekä yksityis- että kansantaloudellisesti haitallista ulkomaisen kilpailun kannalta. Aivan samoin kuin tasauskassoihin vapaaehtoisesti liittyneet yritykset aikaisemmin joutuivat alakynteen kilpaillessaan sellaisten työnantajien kanssa, jotka eivät maksaneet työväestölleen perhelisää, samoin nyt kotimaiset yritykset, jotka laki velvoittaa perhelisiä suorittamaan, ovat heikommassa asemassa kuin niiden ulkomaiset kilpailijat, joilla ei sellaista velvollisuutta ole.

Tämän epäkohdan korjaamiseksi otettiin Belgian lakiin v. 1930 erikoissäädökset, jotka koskivat sellaisia ulkomaalaisia toiminimiä, jotka eivät maksaneet työväelleen perhelisää taikka maksoivat sitä vähemmän kuin Belgian laki edellytti. Milloin tällaiset toiminimet joko välittömästi tai välillisesti saivat hankintoja tai tehtäviä suoritettavakseen valtiolle, maakunnille, kunnille taikka näiden alaisille laitoksille, niiden oli kuukauden kuluessa tehtävän vastaanottamisesta maksettava kansalliselle tasauskassalle sellainen rahasumma, joka mahdollisimman tarkoin vastasi sitä perhelisärasitusta, jonka laki kotimaisille työnantajille asetti. Tämän hinnanlisän vahvisti ammatti-, työ- ja huoltoasiain ministeri tilauksen tehneen laitoksen esityksestä, ja viimeksimainitun tehtäväksi jäi valvoa, että maksu kansalliskassalle todella suoritettiin.?

Tämä toimenpide oli omiaan jossakin määrin tasoittamaan ulkolaisten ja kotimaisten yritysten kilpailua Belgian rajojen sisäpuolella. Ulkolaisilla markkinoilla se ei tietenkään voinut belgialaisia auttaa.

Perhelisät väestöpolitiikan välikappaleen a. Tärkeänä vaikuttimena perhepalkkalainsäädännön alullepanoon ja myöhempään kehitykseen on sekä Belgiassa että Ranskassa ollut se huolestuminen, jota näissä maissa on tun- 
nettu syntyneisyyden jatkuvan alenemisen johdosta. Perhelisien avulla pyrittiin poistamaan ne taloudelliset esteet, joiden katsottiin olevan eräänä syntyvyyttä ehkäisevänä tekijänä. Nyt olisi mielenkiintoista todeta, missä määrin näissä pyrkimyksissä on onnistuttu. Saatavissa olevat numerotiedot eivät kuitenkaan anna tähän kysymykseen varmaa vastausta. Sen seikan, että syntyneisyys Ranskassa 1930-luvulla edelleenkin hiljalleen aleni, ei tarvitse merkitä sitä, että perhepalkkalainsäädännön merkitys olisi ollut tässä suhteessa aivan tehoton, sillä on hyvin mahdollista, että syntyneisyyden aleneminen olisi ilman sitä ollut vielä paljon suurempi. Mitä Belgiaan tulee, siellä syntyneisyyden lasku pysähtyi 1930-luvun puolivälissä, ja vuonna 1938 oli todettavissa jo ilmeistä nousuakin, joka kuitenkin seuraavana vuonna muuttui jyrkäksi laskuksi. Vuodesta 1941 alkaen on kummassakin maassa syntyneisyys miltei jatkuvasti noussut, mutta on vaikeata sanoa, missä määrin se voidaan lukea perhelisäjärjestelmän ansioksi. On näet huomattava, että syntyneisyys on samana ajankohtana noussut monissa muissakin Euroopan maissa, sellaisissakin, joissa perhelisäjärjestelmää ei ole. ${ }^{10}$ Lopullisen vastauksen tähän kysymykseen voinemme saada vasta sitten, kun sodan ja sitä seuranneen ajan poikkeukselliset olosuhteet ovat lakanneet vaikuttamasta tilastonumeroihin.

Mutta vaikka voidaankin pitää todennäköisenä, että perhelisäjärjestelmällä on ollut Ranskassa ja Belgiassa syntyvyyttä edistävä vaikutus, se ei vielä merkitse sitä, että tulos olisi sama myös muissa maissa, jotka niiden esimerkkiä noudattaen ottavat järjestelmän käytäntöön. Asiaan vaikuttaa tietenkin ennen kaikkea se, minkälaiset lakimääräykset kussakin maassa ovat: onko perhelisä yleinen vaiko tulorajasta riippuvainen, korkeako tämä tuloraja on, onko perhelisä yhtä suuri kaikille siihen oikeutetuille luokille vaiko sovellettu edustamaan suurin piirtein samaa arvoa eri elintasoilla oleville perheille, onko se yhtä suuri erä perheen kutakin lasta kohden vaiko lapsen järjestysluvun mukaan nouseva tai aleneva jne. Oleellisin 
merkitys asiassa on tietenkin perhelisän suuruudella. Mitä paremmin se vastaa lapsen huollosta aiheutuvia kustannuksia, sitä suurempi väestöpoliittinen merkitys sillä epäilemättä on.

Perhelisän suuruutta määrättäessä on rahoitusmahdollisuuksiin kiinnitettävä riittävää hưomiota. Belgian lakia vuonna 1930 säädettäessä oltiin tässä suhteessa liian optimistisia. Järjestelmää käytäntöön sovellettaessa kohdattiin ennen pitkää rahoitusvaikeuksia, minkä vuoksi perhelisiä oli alennettava ja rajoituksia niiden saamiselle lisättävä. Tällainen menettely on aina omiaan herättämään tyytymättömyyttä, jotapaitsi se heikentää sitä perhelisien luomaa turvallisuuden tunnetta, mitä on pidetty järjestelmän erikoisena ansiona. ${ }^{11}$

Sivumennen mainittakoon, että varsinkin eräät englantilaiset kirjoittajat ovat suositelleet perhelisiä käytettäväksi ei ainoastaan väestön määrän vaan myöskin sen laadun kohottamiseksi. Tässä tarkoituksessa olisi heidän mielestään suuria perheitä tuettava etenkin niissä luokissa, jotka voivat antaa lapsilleen parhaat takeet turvallisuudesta, terveydestä ja hyvästä kasvatuksesta. ${ }^{12}$ Nämä mielipiteet eivät kuitenkaan ole vaikuttaneet Ranskan ja Belgian perhelisälainsäädäntöön.

Perhelisä ja palkkataso. Vaikka kehitys niin hyvin Ranskassa ja Belgiassa kuin muuallakin on johtanut siihen, että perhelisät ovat menettäneet välittömän kosketuksensa palkkoihin ja alkaneet yhä enemmän muuttua yleisiksi lapsieläkkeiksi, on niiden sekä palkkojen välillä silti edelleenkin olemassa läheinen yhteenkuuluvaisuus. On vaikeata toteuttaa tarkoitustaan täysin vastaavaa perhelisäjärjestelmää ilman, että ennakolta on todettu kunkin väestöryhmän elintaso ja sitä vastaavat minimipalkat, koska muuten on mahdotonta sanoa, tuleeko järjestelmä täyttämään tehtävänsä. Jos näet palkka ei riitä edes kahden täysikasvuisen henkilön välttämätțomiin tarpeisiin, voi perhelisä peittää vain näin syntyvän vajauksen. Päämääräksi on senvuoksi asetettava, että työläisen palkka mahdollisine perhelisineen riittäisi täysin tyydyttämään hänen ja hänen perheensä kaikki kohtuullisiksi katsottavat tarpeet. 
Toinen välttämätön ehto on reaalipalkan säilyttäminen muuttumattomana. Jotta perhelisistä koituva hyöty olisi todellinen, on tärkeätä, että sifä ei neutralisoida elinkustannusten nousulla taikka palkkojen laskulla. Mikäli nämä seikat pääsevät vaikuttamaan, silloin perhelisistä muodostuu vain keino palkkojen osittaiseksi korjaamiseksi elinkustannusten yleistä nousua vastaavaksi.

\section{Kirjallisuusviitteitä.}

1 Landry, Adolphe, Traité de démographie, Pariisi 1945, s. 624. - Picard, Roger, Family Allowances in French Industry, International Labour Review, Vol. IX, No. 2, February 1924, ss. 162-163. - Family Allowances in France, Int. Lab. Rev., Vol. LII, Nos. 2-3, August-September 1945, ss. 196197 ja 208. - Befolkningspolitik i utlandet, Statens offentliga utredningar (SOU) 1944: 26, ss. 64-72. - Betänkande angående gift kvinnas förvärvsarbete m.m. avgivet av kvinnoarbetskommittén, SOU 1938: 47, ss. 143-145.

2 Zeck, Hans $F$., Die bevölkerungspolitische Lage Belgiens und die Errichtung von Kassen zum Ausgleich der Familienlasten, Archiv für Bevölkerungswissenschaft 1934, ss. $41-42$. - SOU 1938: 47, s. 150 .

3 Hoffner, Claire, The Compulsory Payment of Family Allowances in Belgium, France, and Italy, Int. Lab. Rev., Vol. XXXII, No. 4, October 1935, s. 484. - Int. Lab. Rev., Vol. LII, Nos. 2-3, August-September 1945, s. 197.

4 Hoffner, main. kirj., ss. 484 485. - Picard, main. kirj., ss. 171-175.

- Hoffner, main. kirj. ss. 466-468 ja 476-477. 197-198.

6 Hoffner, main. kirj. ss. 469-472. - Family Allowances in France, ss.

7 Hoffner, Claire, Recent Developments in Compulsory Systems of Family Allowances, Int. Lab. Rev, Vol. XLI, No. 4, April 1940, ss. 342-344. Family Allowances in France, ss. 198-199. - Family Allowance Schemes in 1947, Int. Lab. Rev, Vol. LVII, No. 4, April 1948, ss. 317-318.

8 Ranskan järjestelmän esitys perustuu kirjoituksiin Family Allowances in France ja Family Allowance Schemes in 1947. Viimeksimainitun toinen osa julkaistiin Int. Lab. Review'n toukokuun numerossa 1948.

- Urkunden und Gesetze. Belgien: Gesetz betr. allgemeine Einführung von Ausgleichkassen. Unterzeichnet am 4. August 1930. Archiv für Bevölkerungswissenschaft 1934, ss. $77-78$.

10 Bourgeois, Jean, La situation démographique, Population, Revue trimestrielle, 1947, ss. 134 ja $556-559$.

11 Hoffner 1935 , s. 478 . - SOU 1938: 47, s. 161.

12 Hoffner 1935, s. 489. 